\title{
Transforming the Legacy of Indian Residential Schools in Canada into a Public Issue: A Critical Analysis of Michael Burawoy's Public Sociology
}

\author{
Konstantin S. Petoukhov \\ Carleton University, Department of Sociology and Anthropology
}

The Canadian government designed Indian residential school (IRS) system to assimilate Indigenous children into European settler society by dispossessing them of their cultures, languages and traditions. By severing the children's ties to families and communities, and thus integrating them into Euro-Canadian society, the Crown sought to gain control of Indigenous lands (Miller, 2000). In the schools, which were run by church officials, many children died of neglect and diseases and often faced various other injustices perpetrated by staff, including physical, emotional, cultural, and sexual abuse. (Milloy, 1999). Although the last school was closed in 1996, IRS left behind a devastating legacy characterized by sexual and physical abuse in Indigenous communities, substance abuse, loss of Indigenous languages, over-representation of Indigenous people in correctional facilities, and others. Until recently, these were considered to be private issues. However, the growing body of evidence demonstrates that IRS were responsible for the negative impacts and the government and churches were compelled to recognize the damage done. This article explores Michael Burawoy's (2005) four types of sociology (policy, critical, professional, and public) and assesses the relative contributions of each type in the process of transforming "private troubles" of the IRS legacy into "public issues." The main thesis of the article is that each type of sociology, with varying degrees of success, promotes the recognition of the injustices inflicted by IRS. The article concludes that Burawoy's sociology possesses its strengths and weaknesses in identifying private troubles as public issues.

Keywords: sociology; public sociology; residential schools; aboriginal.

Le gouvernement canadien a conçu des pensionnats autochtones (PA) pour assimiler les enfants indigènes dans la société des colons européens en les dépossédant de leurs cultures, langues et traditions. En rompant les liens de l'enfant avec ses familles et communautés, et donc en les intégrant dans la société euro-canadienne, la Couronne a tenté de prendre le contrôle des terres autochtones (Miller, 2000). Dans les écoles, qui ont été dirigées par les responsables de l'église, plusieurs enfants sont morts suite à des négligences et des maladies et ont souvent fait face à diverses injustices commises par le personnel, y compris des abus physiques, émotionnels, culturels, et sexuels. (Milloy, 1999). Bien que la dernière école ait été fermée en 1996, les PA ont laissé derrière eux un héritage dévastateur caractérisé par des abus physiques et sexuels dans les communautés autochtones, la toxicomanie, la perte des langues autochtones, la surreprésentation des peuples autochtones dans les établissements correctionnels et autres. Jusqu'à récemment, ces conséquences ont été considérées comme des questions privées. Toutefois, un nombre croissant de preuves démontre que les PA ont été responsables de ces impacts négatifs et le gouvernement et les églises ont été obligées de reconnaître les dommages causés. Cet article explore les quatre types de sociologie (2005) de Michael Burawoy (académique, critique, experte et publique) et évalue les contributions relatives de chaque type dans le processus de transformation des "problèmes personnels » de l'héritage des PA en "questions d'intérêt public. » La thèse principale de l'article est que chaque type de sociologie, avec divers degrés de succès, encourage la reconnaissance des injustices infligées par les PA. L'article conclut que la sociologie de Burawoy possède ses forces et ses faiblesses dans l'identification des problèmes personnels comme des problèmes publics.

Mots-clés: sociologie, la sociologie publique; pensionnats; autochtones. 
Recent scholarship on reparations for the legacy of Indian residential schools (IRS) has focused on assessing the mechanisms of redress and their potential to repair the harm done. The goal of this paper is to adopt a critical approach that examines the role of public sociology in the process through which "private troubles" arising from IRS injustices attained public and political dimensions, which compelled the recognition of IRS experiences. In doing so, I pose the question, "How has the legacy of IRS, (which is characterized by increased rates of violence in Indigenous communities, substance abuse, suicide, and many other dysfunctions) come to be viewed as the result of IRS?" To answer this question, I will employ Michael Burawoy's four types of sociology: public, professional, policy, and critical. Through these four types I will consider their relative strengths and weaknesses (or "legitimacies" and "pathologies, as Burawoy calls them) and the contributions of each type of sociology to the process of "publicization" of the residential school legacy. According to Burawoy, each type of sociology has a public face, and can be considered to contribute "at least potentially ... to the transformation of private troubles into public issues" (O'Connor, 2006, p. 8).

\section{Background}

The Canadian government established the IRS system in the late $19^{\text {th }}$ century with the goal of assimilating Indigenous children into Euro-Canadian society. The schools were designed to function as "total institutions" and sought to isolate the children from the influence of their families and home communities (DeGagné, 2001). IRS were run by the churches (Roman Catholic, Anglican, United, and Presbyterian) and sought to strip away the children's cultural identities, including the languages, customs, and traditions. One of the goals of IRS was to proselytize the children, teach them English or French, and to provide them with basic skills that would allow them to function successfully in a settler society (Miller, 1996). In IRS, the children encountered various types of abuse, including physical, sexual, cultural, and psychological. The horrific living conditions in the schools caused many children to die of neglect and diseases (Schissel \&Wotherspoon, 2003; Haig-Brown, 1988).

Although the last residential school closed its doors in 1996, the IRS system left behind an appalling legacy, which includes "increased violence, increased suicide rates, increased substance abuse, and increased family disintegration" in Indigenous communities across Canada (Smith, 2009, p. 30; Grant, 1996). Many Indigenous languages, customs, and traditions became extinct as a result of IRS. Recognizing the impact of IRS, many survivors launched civil suits against the Canadian government and churches to seek redress for the legacy of IRS and the abuse and neglect that took place in residential schools (Smith, 2007). Faced with an overwhelming number of lawsuits that threatened to bankrupt the government and churches, the accused parties offered apologies that sought to acknowledge the impact of IRS. However, the apologies failed to satisfy survivors' needs for justice due to the perceived lack of sincerity and acknowledgement of the harm done O'Connor, 2000; Younging et al., 2009).

In response to the apparent failure of these apologies to bring an end to the lawsuits against the federal government, various mechanisms of redress have been established. These include an Alternative Dispute Resolution (ADR) process and the 2006 Indian Residential Schools Settlement Agreement (IRSSA). The latter consisted of a three-pronged approach: The Truth and Reconciliation Commission (TRC), commemoration initiatives, and compensation payments for survivors. Although the complicity of the government and churches in IRS injustices has been thoroughly documented (through the reports released by the Royal Commission on Aboriginal Peoples (1996) and affirmed by successful lawsuits brought forward by IRS survivors) it is important to examine the processes through which the legacy of IRS ceased to be viewed as a problem of individual survivors and began to be considered a systemic, public, and political issue. 


\section{Making the Private Public}

According to Pamela O'Connor (2000), for many decades, the legacy of IRS has been categorized as what Pat O'Connor (2006) calls "private troubles" (p. 6). That is, the negative consequences of IRS were not considered products of the residential school experiment, but instead viewed as isolated, individualized cases of abnormalities among former IRS students (Stout \& Kipling, 2003). For example, family dysfunction, higher-than-national crime rates and instances of sexual abuse in Indigenous communities, and increased suicide rates among former IRS students have historically been attributed to individual survivors, and not as the outcomes of residential schooling (Hodzic, 2011). The transformation of these "private troubles" into "public issues" began once the connection between IRS experiences and their legacy was made abundantly clear by the 1996 Royal Commission on Aboriginal Peoples (RCAP) Report. The report covered "a vast range of issues," including the evidence of the damage done by the residential school system, and provided recommendations to the federal government on how to rebuild the relationships between Indigenous and non-Indigenous peoples (United Nations, 2009, p. 4). Although many of the report's recommendations were never implemented, it prompted a paradigm shift that consisted of lifting the blame from the victims of residential schooling and fostering an understanding of the IRS legacy as the product of the colonial project, thereby transforming the IRS legacy into a public issue (IRS TRC, 2008).

Before interrogating the process of recognition of the legacy of IRS as a public issue and problematizing it as a private trouble, one must begin by reviewing the reasons why it has historically been considered a private trouble. O'Connor (2006) argues that the issue of power constitutes the foundation for a process in which certain private troubles, and not others, tend to become public issues. In her analysis of patriarchy in Irish society, she suggests that societal relations between men and women become ingrained in a hierarchy. This "bias, [which] is taken for granted ... is seen as natural and inevitable," and produces and reproduces gender inequality (p. 7). In her view, this effectively precludes certain private troubles from taking on the public face.

A similar argument can be applied to the issue of the legacy of residential schooling. More precisely, one could argue that the perceived superiority of European cultures and Eurocentrism have long been used by the Canadian government as a mechanism to justify the oppression of the less powerful Indigenous Nations. Socially, economically, and politically disadvantaged, Canada's Indigenous peoples have historically been unable to challenge the unequal power relations that exist between them and the settler government (Episkenew, 2009). However, the late $19^{\text {th }}$ century has seen a power shift in favour of Indigenous peoples that ensures that the residential school legacy will no longer remain masked as private troubles. Policy sociology provides a partial account of this shift by considering the factors that contributed to the publicization of the IRS experience.

\section{Policy Sociology}

Burawoy's (2005) policy sociology is "sociology in the service of a goal defined by a client" who is typically located outside academia (p. 9). Policy sociology's focus can be broad or issue-specific, and its legitimacy lies in its ability to solve clients' problems effectively. Its pathology, on the other hand, is its servility to the client's will. The clients of policy sociology are represented by a diverse range of groups and may include interest/lobby groups, government organizations, or private individuals. As Burawoy points out, policy sociology's clients may possess specific defining membership characteristics or be intentionally inclusive. To exercise its problem solving ability, policy sociology employs instrumental knowledge; that is, it draws on an existing body of knowledge within sociology to come up with solutions. For example, according to Baker et al. (2004), policy sociology can have an impact on government policy by providing solutions or recommendations, as well as serve as a "vital tool for keeping the state publically accountable" (p. 170). Jonathan Turner (2005), a strong advocate of policy sociology, believes that it is its ability to be employed as a tool for "social engineering" that makes it the single most influential type of sociology (p. 39). 
In the process of the "publicization" of the legacy of residential schools, policy sociology's contribution can be considered in terms of its potential to raise awareness and demonstrate the systemic nature of problems that survivors, their families, and communities are currently facing. Arguably, the two distinct publics that are the key stakeholders in this struggle are IRS survivors and the Assembly of First Nations (Canadian Bar Association, 2005). The broader goal that guides the actions of these publics (clients) is to hold the Canadian government and churches accountable for the implementation and maintenance of the residential school system (Assembly of First Nations, 2004). To achieve this goal, the stakeholders rely on the expertise supplied not only by policy sociologists, but also legal scholars, criminologists, Native studies researchers, and political scientists engage with these policies. The ultimate goal is to put pressure on the federal government and to compel it to recognize and adequately respond to the legacy of residential schools. By working together in an interdisciplinary manner or within their respective disciplines, the objective of the scholars is to advance the interests of their clients. In order for its strategies to be effective, policy sociology must possess a clear goal and purpose, and in the case of IRS, to ensure that survivors and their communities are on the path to healing, peace, and justice.

One of the ways in which policy sociology can serve its publics in the context of the residential schools is by providing the evidence that substantiates the claims that IRS have had a profound detrimental impact on the lives of survivors, their families, and communities. Monchalin (2009), for example, argues that the damage done by the residential schools is apparent in intergenerational problems that are reflected in the "high rates of both victimization and offending" among Indigenous populations (p. 1; see also Grant, 1996). As well, assimilationist practices of the Canadian government led to higher-than-national rates of arrests, convictions, and imprisonment of Indigenous peoples (LaPrairie, 1999). Furthermore, by depriving Indigenous peoples of their languages, customs, and traditions, the schools have contributed to "cultural marginality," which often resulted in shorter-than-national life-span among Indigenous peoples, increased rates of alienation on reserves, and high suicide rates (Waldram, 2009). Cindy Blackstock (2008), in turn, argues that in addition to family dysfunction that resulted in "higher rates of incidence of physical and emotional harm," the current rates of Indigenous children in care of child and family services are much higher than those of non-Indigenous children (p. 167).

The evidence of IRS abuse and neglect is also striking. John Milloy (1999), for example, argues that the death rates among residential school students were as high as 69 percent, and around 42 percent of children died shortly after "being sent home when they became critically ill" (Smith, 2009, p. 9). Furthermore, the evidence indicates that many children were physically, sexually, and psychologically abused in residential schools and the majority of perpetrators were church officials and school staff (Miller, 1996). Milloy (1999) notes that the rates of sexual abuse were such "that eight out of ten girls under eight years of age were victims of sexual abuse, and five out of ten boys were also sexually abused" (p. 298). In her paper, Andrea Smith (2009) observes that IRS students, who later become parents, encounter serious difficulties in transmitting traditional Indigenous values and knowledge to their children.

In addition to supplying evidence, the pragmatic nature of policy sociology also necessitates a search for solutions that would address the clients' problems. In the context of residential schools, scholars such as Pamela O'Connor (2000) and Alfred Taiaiake (2009) argue that in order to begin to address the legacy of IRS, the government must provide reparations to residential school survivors. Criminal justice scholars such as Elizabeth Kiss (2000) point out that in the cases of human rights violations, formal admissions of responsibility such as an apology and acknowledgements of the harm done may play a therapeutic role for victims. Similarly, traditional justice expert Martha Minow (1998) adds that an apology could serve as one of the critical steps that "officials can take to promote reconciliation and healing in the context of political and interpersonal violence" (p. 114). On the other hand, restorative justice scholars such as Strang and Braithwaite (2001) caution that other types of reparations, namely monetary compensation, must be coupled with an apology in order to demonstrate that the apology is not simply "empty words" or "lip-service." While there may be a multiplicity of possible strategies that seek to begin to provide redress for the IRS legacy, they all carry the same goal, which is to ensure that the government is held accountable for its actions. 
Overall, policy sociology appears to be an effective mechanism that influenced the process of recognition and publicization of the residential school legacy, which in turn helped to remove the negative stigma from former students for the difficulties they are currently facing in their lives. By utilizing the indisputable evidence of the abuse that took place in residential schools, Indigenous political groups, such as the Assembly of First Nations (AFN), were able to demonstrate the harm done by the Federal government and churches. The indigenous political groups were also able to compel these parties to provide reparations for the residential school experience (Castellano et al., 2008). However, it is important not to forget the impact of Indigenous grassroot organizations on the process of recognition of the IRS legacy.

Indigenous non-government organizations such as the Native Women's Association of Canada (NWAC) and 1000 Conversations played a role in raising awareness of and lobbying for the impact of IRS injustices (NWAC, 2011). In addition, First Nation Child and Family Caring Society (FNCFCS) regularly publishes reports and journal articles that demonstrate the ways in which the legacy of IRS is producing negative consequences for Indigenous children, families, and communities (FNCFCS, 2012). Policy sociologists have been able to draw on the evidence produced by these organizations to promote the recognition of the IRS legacy. On the other hand, controversial movements such as Hidden from History and International Tribunal into Crimes of Church and State (ITCCS) have been widely criticized by Indigenous peoples, leaders, and academics across Canada for misrepresenting the IRS legacy and for equating it with the Holocaust (Diamond, 2011; Annett, 2010).

Although policy sociology often provides solutions to clients' problems by providing and justifying potential solutions, its ability to produce meaningful societal change is limited by its dependence on the clients' agendas (O'Connor, 2006). More specifically, it lacks reflexive knowledge, which Burawoy (2005) defines as "[the knowledge that] is concerned with a dialogue [between academics and publics] about ends" (p. 11). In the case of the residential school legacy, the problems defined by the public (the AFN, survivor groups, etc.) were narrow in scope in that it sought to redress only the consequences of residential schooling. The limited objectives of this agenda leave untouched the broader colonial forces that gave rise to the residential school system. Thus, by focusing only on the residential school experiences, policy sociology effectively ignores the systemic nature of harms that colonialism produced and continues to produce. This selectivity narrows the discussion of harms and inequalities that Indigenous peoples suffer in the areas of health care, politics, child welfare, education, and others (Alfred, 2009). This inherent pathology of public sociology could lead to what Gregg Olsen (2002) refers to as non-decision making that signifies the creation of boundaries around the debate by selectively introducing some issues, while leaving others out of consideration.

A second, and related, challenge that policy sociology faces is concerned with its lack of normative valence (Burawoy, 2005). That is, policy sociology is unable to determine and assess the direction of agendas that its clients put forth and to ensure that the clients' goals have, in fact, been achieved. In other words, policy sociology does not have an evaluative function that would allow it to conduct a normative appraisal of the clients' objectives nor does it ensure that the end result is, in fact, desirable for the clients (Brym \& Nakhaie, 2009). For example, policy sociology is unable to measure how effectively the legacy of residential schools is addressed through the solutions that policy sociology proposes. The provision of an apology to IRS survivors, the implementations of the IRSSA, and the establishment of the TRC may all be goals of the clients of policy sociology. However, the question that it may be unable to answer is, will these mechanisms adequately address the legacy of IRS?

Despite its apparent limitations, policy sociology appears to make a significant contribution to the transformation of private troubles arising from the legacy of residential schools into public issues. Now the question becomes, in what ways does professional sociology promote the recognition of the IRS legacy as a public issue?

\section{Professional Sociology}

According to Burawoy (2005), professional sociology informs sociological approaches by supplying "true and tested methods, accumulated bodies of knowledge, orienting questions, and conceptual frameworks" 
(p. 10). Professional sociology consists of "well established ... multiple intersecting research programs" and constitutes sine qua non of policy sociology by "providing [it with] both legitimacy and expertise" (Burawoy, 2005, p. 10). Its research programs generate empirical, scientifically-derived knowledge and invest it with a puzzle-solving ability. The main audience of professional sociology is the academic community, which includes students (O'Connor, 2006). The public faces of professional sociology appear when academic knowledge produced by professional sociology is disseminated by scholars and made accessible to the public. Like policy sociology, professional sociology produces instrumental knowledge, and its pathology is self-referentiality (Brym \& Nakhaie, 2009).

Although the knowledge generated by professional sociology is intended mainly for the academic audience, it has sometimes been employed by groups outside academia to achieve their objectives. For example, Indigenous justice and self-determination movements in Canada have been making use of various sociological theories and methods (including power resource theories, critical theories, and stratification theories, as well as qualitative/quantitative research methods) to politicize their goals (Delgado, 2001). These include claims to Indigenous sovereignty, opposition to systemic discrimination, and the impetus for establishing culturally appropriate justice systems in Indigenous communities (Ivison et al., 2000). Here, we can see the overlap between the public faces of professional and policy sociologies (although it should be noted that the knowledge produced by policy sociology is "concrete [as] required by policy clients,") whereas professional sociology's knowledge is meant to develop research programs within the discipline (Burawoy, 2005, p. 16).

Given its potential to promote the legitimacy of sociology, professional sociology has been slow to respond to the paradigm shift around the discourse of the legacy of residential schools. Let us consider the case of the Canadian Sociological Association (CSA), which has been producing the Canadian Review of Sociology (CRS) since 1964 that publishes academic articles which discuss contemporary issues in Canadian society. Among the publications are articles that address the problems that First Nations, Métis, and Inuit peoples are facing. These often include income and educational inequalities, contemporary political struggles, health and well-being outcomes among Indigenous populations, and others (Dyck, 1997; Bischoping \& Fingerhut, 1996). However, the CRS has attracted only a small number of articles analyzing the legacy of IRS and its connection to the systemic nature of harms that survivors and their communities are experiencing as the result of residential schooling. Thus, the journal has not significantly contributed to the identification of the IRS legacy as a public issue. The CSA has also published the second edition of its reader, Reading Sociology: Canadian Perspectives (2011), which include some chapters that discuss Indigenous and non-Indigenous relations in the $21^{\text {st }}$ century, but none of its content directly addresses the legacy of residential schooling.

In addition to the CSA publications, it is also important to examine the research programs within professional sociology and their focus on the IRS legacy. Theories of internal colonialism inform professional sociological approach and identify the cultural sites at which colonization had a negative impact on the lives of Indigenous peoples (Gartrell, 1986). They locate the IRS system as one of the mechanisms that was established to oppress and subjugate Indigenous Nations in Canada (Schissel \& Wotherspoon, 2003). The theory posits that the IRS system was remarkably successful at dispossessing Indigenous children of their cultures, values, and traditions, and producing communities stricken by poverty, crime, and spiritual emptiness. Thus, the internal colonialism approach situates systemic issues as one of the root causes of the dire situation that Indigenous peoples find themselves in the post-IRS era.

In addition to building theoretical frameworks, professional sociology demonstrates reflexivity by identifying the academic research programs within sociology that have historically led to the marginalization and colonization of Indigenous research. In their work, Wilson (2008), Kovach (2009), and Brown and Strega (2005) discuss the contexts in which Indigenous peoples have predominantly been subjects of academic research rather than active participants. They suggest that the methodologies that have traditionally been used to study Indigenous issues have been characterized by positivist approaches and qualitative/quantitative dichotomies, as opposed to traditional Indigenous knowledge systems. Brown and Strega (2005) argue that this type of research, or any type of mainstream sociological research, fails to incorporate the anti-colonial elements that are required to challenge the basis of oppression upon which 
Indigenous/non-Indigenous relations have been built in the past. Brown and Strega (2005) go on to point out that much of the current research involving Indigenous peoples is characterized by methodological hierarchies that make minimal contribution to stimulating the debates around the hegemonic nature of mainstream social research, while "quantitative research [in social sciences]...continues to be the gold standard for social science research" (p. 8).

Shawn Wilson (2008) offers a contrasting, yet complementary insight into traditional research methodologies in professional sociology. He argues that historically, research involving Indigenous peoples sought to examine only those issues that it saw relevant to its ideologies, as opposed to being guided by the moral and ethical principles. He calls for more participation of Indigenous researchers in studying the issues relevant to Indigenous populations. However, by making a case for greater participation of Indigenous researchers, Wilson assumes that Indigenous researchers would conduct research that is drastically different from that carried out by non-Indigenous scholars. What he does not take into account is that much of Indigenous knowledge has been transformed in the process of colonization. As Kovach (2009) argues, for example, there have been various attempts within academic institutions to compartmentalize Indigenous research into the qualitative research category. Additionally, Indigenous researchers are forced to conduct their studies within broader frameworks of mainstream theories, knowledge, and methodologies. To step outside of these frameworks is to risk losing legitimacy and as Wilson (2008) puts it, "Indigenous peoples are held down by [Western] research and the dominant view of knowledge and the world is upheld" (p. 17). Although the "new wave" of Indigenous research has increased its academic presence since the 1970s, it reached a decolonizing phase beginning in the early 1990s.

Indigenous knowledge and research methodologies have been met with resistance and obstacles in Canadian academic institutions for various reasons. First, there seems to be general confusion within academia with regard to implementation strategies and the introduction of an Indigenous research paradigm into the existing (Western) research programs (Kovach, 2009). To overcome this challenge, Canadian academic institutions would be required to begin to recognize and accept Indigenous research programs as legitimate modes of knowing and knowledge production. Secondly, Western academia would need to be reflexive and acknowledge the "historical influence of Indigenous-settler relations on educational policy" (Kovach, 2009, p. 157). To date, academic institutions in Canada have been somewhat resistant to change the existing educational order and incorporate Indigenous research paradigms alongside mainstream research programs.

In Canada, professional sociology, and its research programs in the context of the transformation of the IRS legacy into public issues are weak. While the interest in emerging Indigenous research and knowledge production is growing, it is too soon to ascertain whether they will receive the necessary recognition and acceptance from mainstream educational institutions in order to be deemed legitimate. Professional sociology's pathology of self-referentiality plays a significant role in keeping its focus mainstream and resisting the introduction of new research programs. It often fails to challenge the takenfor-granted validity of theories and methods that it supplies and their applicability to studying the residential school legacy. In contrast, critical sociology attempts to introduce change into the existing research programs and to produce alternative ways of conducting research.

\section{Critical Sociology}

Critical sociology performs an innovative and dynamic function within the discipline by interrogating the existing values of professional sociology and by "promoting new research programs built on alternative foundations" (Burawoy, 2005, p. 10). The main goals of critical sociology are to compel mainstream/traditional sociologists to re-examine and re-think social problems by applying creative sociological perspectives, which are markedly different from those supplied by professional sociology, and to foster a debate between and within the existing research programs. As a corollary, the audience of critical sociology is primarily academic, although Burawoy (2005) argues that in some cases, it engages with and even serves the public. Burawoy (2005) also suggests that critical sociology is the conscience of professional sociology, while its legitimacy is its moral vision. Normative valence drives it to create "what 
can crudely be described as a 'better world"' (O'Connor, 2006, p. 11). Critical sociology generates reflexive knowledge that is achieved through a dialogue between intellectuals within sociology and to a lesser extent, between intellectuals and the public. Burawoy (2005), however, identifies critical sociology's pathology as dogmatism.

In the context of the residential school legacy, critical sociology attempts to establish new research programs by posing questions such as, "What are the inadequacies of current research programs in sociology that consider the legacy of IRS?" and "How can these programs be revised to become more responsive to the research needs of Indigenous peoples?" Being acutely aware of the systemic factors that are responsible for the subordination of Indigenous Nations throughout colonization, critical sociology seeks to transform professional sociology's current research programs (Battiste \& Henderson, 2009). Critical sociology problematizes the existing mainstream/traditional research programs by exposing the settler values and ideologies that form their foundations. For example, critical sociology attempts to introduce Indigenous concepts of "healing," "justice," and "peace" into Indigenous research projects (Smith, 1999). The implementation of these elements may initially prove difficult for Western research programs to accept, conceptualize, operationalize, and evaluate. Thus, there is a need for critical sociology to continue to interrogate values, traditions, and principles on which Western research is currently premised. In her work advocating decolonization in Indigenous research, Kovach (2009) notes that to date "there has been little systemic shift in the ideology of knowledge production" (p. 28). For Smith (1999) and Kovach (2009), decolonizing methodologies is a critical step in the process of challenging Euro-Canadian hegemony that has historically guided the research in the area of residential schools.

One of the tools available to critical sociologists for the study of the legacy of IRS is critical race theory (CRT). Among the questions that CRT poses are those related to "interpret[ation], prioritiz[ation], and own[ership of] research products and research" that is conducted to study issues related to Indigenous populations (Brown \& Strega, 2005, p. 7). Critical sociology scholars point out that decolonization of Indigenous research represents one of the ways in which Indigenous peoples and their communities may be empowered to overcome the continuing Western/settler subordination and subjugation. By examining the current Indigenous research programs through the lens of critical sociology and CRT in particular, it is apparent that they have traditionally been established predominantly on Western "classification, representation, and evaluation" (Smith, 1999, p. 43). More specifically, this type of research can be describes as uni-cultural or uni-traditional and driven by European values, thereby instilling an imperialstic/colonial bias that would serve as an obstacle to the transformation of private troubles into public issues. Critical sociology argues that by employing these research methodologies and theories, traditional sociologists as researchers run the risk of conceptualizing the legacy of IRS through a Eurocentric lens. For example, Smith (1999) argues that even the definitions of individuals and society, as well as time and space, are conceptualized in Indigenous cultures differently from how they are defined in Euro-Canadian society.

By applying reflexive knowledge, critical sociologists are able to generate new research programs that are based on alternative conceptual and theoretical frameworks. Indigenous healing programs represent some of the models that have recently been gaining momentum within Western research programs seeking to address the legacy of the residential schools. Although certain aspects of the healing programs (many of which are offered by the Aboriginal Healing Foundation) have been developed through negotiations with Health Canada, they are often considered to be inspired by Indigenous justice and healing traditions and seeks to promote the recognition of the harm done by residential schools to individuals and communities (Brasfield, 2001). They are also considered by many Indigenous and non-Indigenous scholars as potential sources for decolonization, transformation, and socio-political change (Castellano et al., 2008). Although the main goal of critical sociology is to promote a debate within the discipline, it helped to stimulate the extra-academic discussion of the social causes of the damage done to Indigenous peoples and their communities.

While critical sociology has also contributed to the changes in the scholars' perceptions of the depth and seriousness of the consequences of the IRS legacy, its public faces are apparent in its attempts to foster the notions of moral responsibility and ethical obligations in the process of redressing the residential school 
experiences. For example, researchers such as MacKenzie (2009) argue that ethical principles of recognition, acknowledgement, and reparation of the harm done should guide Canadian government's actions. William Mussell (2008), on the other hand, points out that by addressing the legacy of IRS, the government has the obligation to support Indigenous Nations in transition to greater self-determination, which would contribute to decolonization of Indigenous political, social, cultural, and economic processes. In other words, the government would need to recognize the forces within the broader colonial project (such as Euro-centrism and perceived inferiority of Indigenous peoples) that led up to the establishment of the IRS system. Mussell goes on to point out that decolonization will help foster a renewed relationship between Indigenous peoples and the Canadian government that is based on peaceful co-existence and mutual recognition (p. 338).

The work of critical Native Studies scholars has also influenced Indian residential school resistance, healing, and reconciliation movement in Canada. For example, Chrisjohn and Young (1997) expose the inadequacy of considering residential school trauma in isolation from other injustices that Indigenous peoples continue to suffer. Chrisjohn and Young (1997) refer to the demarcation of residential school trauma from the broader colonial context as individualizing, personal and internal and argue that it should be labeled "genocide, institutional racism, and economic oppression" (p. 62). By applying these labels to residential school experiences, Chrisjohn and Young (1997) are able to reframe the politics of residential schooling. This reframing, in turn, helped to solidify Indigenous rights movements, to which residential schools and Indigenous health, education, and politics were an integral part. Alternative methodologies move beyond "methodological individualism" and position the resolution of the residential school experiences as a crucial step in rebuilding the relationship between Canada and its Indigenous peoples (Chrisjohn \& Young, 1997, p. 58). Organizations such as the AHF and associations such as the Indian Residential School Survivor Society (IRSSS), for example, recognize the importance of adopting a holistic approach to healing residential school trauma. The final section of this paper examines public sociology, its engagement with non-academic audience, and its ability to transform private troubles arising from the legacy of IRS into public issues.

\section{Public Sociology}

Burawoy's (2005) public sociology consists of two types: organic and traditional. Traditional public sociologists do not engage directly with the public and choose to address issues of public importance in indirect ways, which include writing "in the opinion pages of our national newspapers" (p. 7). Because traditional public sociology's methods of engagement generate little interaction between academic and nonacademic groups, publics such as social movements, or in the case of IRS, Indigenous groups, escape the focus of traditional public sociologists. Organic sociologists, on the other hand, constitute the majority of public sociologists and work closely and directly with thick and visible publics. As Buarwoy (2005) notes, these often include counter-publics such as "labor movements, neighborhood associations, communities of faith, immigrant rights groups, [and] human rights organizations" (p. 8). Organic public sociology's raison d'être can be contrasted with those of critical and professional sociologies. More specifically, whereas a dialogue informs the relationship between organic public sociologists and publics, a top-down approach characterizes the relationship between professional/critical sociologists and publics. What unites organic and traditional public sociologies is their ability to "make visible the invisible [and] to make the private public ... as part of our sociological life" (Buarwoy, 2005, p. 8).

Recent academic research on the legacy of IRS focuses on examining the relationship between the harms of residential schools and criminalization of the IRS legacy. In her work, Canadian sociologist Carol LaPrairie (1999) conducted research on settler-Indigenous relations, Indigenous peoples in corrections, and the legacy of the residential schools. Within the dichotomy of public sociology, LaPrairie (1999) can be classified as an organic public sociologist in her earlier work because she directly engages with a Indigenous communities, and her research has been influential in producing social change, particularly in the area of criminal justice and Indigenous peoples, and has been adopted by the Indigenous justice movement (Dickson-Gilmore \& LaPrairie, 2005). Later in her career, LaPrairie (1999) shifted her focus to addressing 
correctional policy issues and working for the government, as well as advocating the restorative justice approach to address crime. As a traditional public criminologist, much of her work is built on a thesis that because of its transformative potential, the restorative justice paradigm is able to address the wrongs that the horrific legacy of residential schools has gives rise to. By considering Indigenous and restorative justice approaches as tools for dealing with the legacy of colonialism and residential schools, LaPrairie's (1998, 1999) research has been instrumental in promoting the recognition that restorative justice is a viable alternative to criminal justice for combating systemic issues, such as Indigenous over-representation in correctional institutions. The Aboriginal Healing Foundation's From Truth to Reconciliation: Transforming the Legacy of Residential Schools (2008), for example, builds on LaPrairie's (1999) ideas that help to frame the legacy of IRS as a systemic issue.

Canadian scholar Marianne O. Nielsen (1994), an organic public sociologist/criminologist, has been influential in the area of promoting culturally appropriate justice models in Canada, problematizing the applicability of Western justice to the crime committed by Indigenous peoples, and recognizing the present-day issues that Indigenous peoples are facing as results of colonial legacies. Much like La Prairie, Nielsen works with what Burawoy (2005) calls "thick, visible public," such as Indigenous social justice groups, political activists, and grass root organizations (Nielsen \& Gould, 2007). Although Nielsen is a criminologist by training, some of her work has been influential in the area of political sociology. For example, her contributions to the recognition of the IRS legacy as a public issue include the impetus for decolonization of Indigenous self-determination in relation to political and justice processes. Nielsen's (1994) and Nielsen's and Zion's (2005) research also focuses on the ability of Indigenous peoples to advance their interest with regard to establishing culturally appropriate mechanisms to holistically address the legacy of IRS. Nielsen (1994) builds on the work of Native studies scholars such as Monture-Angus (1999) and traditional public criminologists Philip Stenning and Julian Roberts (2001), who argue that Indigenous crime in Canada is by and large the product of IRS and systemic discrimination. Similarly, Nielsen (1994) suggests that a successful resolution of the legacy of IRS is connected to reframing crime as a public issue and requires establishing justice processes that would recognize historical origins and causes of Indigenous crime. More specifically, Nielsen and Robyn (2003) point out that such processes would take into account the loss of Indigenous languages and cultures, aggressive religious indoctrination, physical abuse, and the resulting "tremendous community and family disorganization" (p. 37).

Organic public sociologists such as Deb Sider (2005) have partnered with community grassroot organizations Sioux Lookout Anti-Racism Committee and Nishnawbe-Gamik Friendship Centre to politicize the IRS legacy by drawing connections between present day disadvantages that Indigenous peoples and their communities are facing and the injustices that took place in IRS. For instance, Sider's analysis demonstrates how Indigenous homelessness, language loss, and negative health outcomes are directly linked to the IRS legacy. Also, public sociology has been influenced by Indigenous scholars and activists such as Alfred Taiaiake and Jeff Corntassel (2005). The work of these scholars helped to situate the legacy of IRS as part of a broader range of injustices that Indigenous peoples are encountering and made contributions to Indigenous justice movements that were aimed at decolonizing Canada and empowering Indigenous peoples. Similarly, non-Indigenous scholars like Peter Kulchisky (2010), have begun social movements (such as Defenders of the land and Indigenous peoples solidarity movement) to demonstrate the nature of systemic harms that Indigenous peoples are facing, many of which stem from the IRS era.

Upon examining the work of public sociologists and criminologists in the process of transforming the legacy of IRS into a public issue, it is apparent that the majority of their contributions cannot be easily categorized in the realm of either traditional or organic public sociology. This finding runs contrary to Burawoy's (2005) argument that the "bulk of public sociology is indeed of an organic kind" (p. 7). The contributions of organic public sociology with regard to the transformation of the legacy of residential schools are limited in Canada. Although there has been a significant amount of research done by traditional public sociologists in his area, there has been a lack of direct interaction and engagement between academics and publics (Indigenous activist groups, former IRS students, and communities affected by residential schooling). Thus, public sociology has overall made a less significant impact on the framing of the legacy of IRS as a public issue than it otherwise could have. However, public sociology has succeeded, 
to a certain degree, in promoting the recognition of residential schools as a product of colonialism, structural disadvantages, and systemic discrimination.

\section{Conclusion}

This paper examined the public faces of each of the four types of Burawoy's (2005) sociology and their ability to transform private troubles arising from the residential school experience into a systemic issue of public concern. The analysis of policy, professional, critical, and public sociologies reveals inconsistencies across all four types in their contribution to the identification of the IRS legacy as a public issue. Policy sociology seems to have made the most meaningful and profound contribution to the framing of the IRS legacy as an issue that stems from the abuse and neglect students faced in residential schools. Critical sociology, in turn, stimulated the debate within the discipline and articulated the need for alternative research programs that would recognize the public face of the IRS legacy. Professional sociology and its legitimacy of "true and tested methods, accumulated bodies of knowledge, orienting questions, and conceptual frameworks" helped to ensure the sustained resistance to framing the IRS legacy as a private issue within and outside academia (Burawoy, 2005, p. 10). Lastly, traditional public sociology has been more prominent than organic public sociology in promoting the recognition of the public nature of IRS experiences. In addition to sociology's contributions, it is apparent that academics from other disciplines namely law, history, Native studies, and anthropology also played an active role in framing the IRS legacy as a product of systemic forces.

Overall, Burawoy's (2005) model provides a useful framework for examining the process of transformation of private troubles into public issues. An evaluation of the relative strengths and weaknesses of each type of sociology allows one to examine the limitations, advantages, idiosyncrasies, and significance of this approach in promoting social change, whether it is by fostering a debate within sociology or creating partnership between academics and non-academic publics. Finally, this paper confirms Burawoy's (2005) thesis that each type of sociology has a public face and the impetus to "defend the interests of humanity" (p. 24).

About the Author: Konstantin Petoukhov is a Ph.D. student in the Department of Sociology and Anthropology at Carleton University. His Master's research focused on Canada's Truth and Reconciliation Commission, restorative justice, and the theory of recognition. For his doctoral research, he plans to examine the extent of self-determination of Indigenous peoples in Canada and Australia by considering socio-cultural, political, and economic institutions. He can be reached at: kpetoukhov@live.ca

\section{References}

Aboriginal Affairs and Northern Development Canada. (2008). Backgrounder - Indian residential schools settlement agreement. Retrieved May 11, 2012 from http://www.aadncaandc.gc.ca/eng/1100100015755.

Alfred, T., \& Cortassel, J. (2005). Being Indigenous: Resurgences against contemporary colonialism. Politics of Identity, 9, 597-614.

Alfred, T. (2009). Restitution is the real pathway to justice for Indigenous peoples. In G. Younging, J. Dewar, \&M. DeGagné (Eds.), Response, Responsibility, and Renewal: Canada's Truth and Reconciliation Journey (pp. 179-190). Ottawa: The AHF.

Annett, K. (2010). Hidden from history books systematically destroyed across Canada, TheIntelHub, November 3.

Assembly of First Nations. (2004). Report on Canada's dispute resolution plan to compensate for abuses in Indian residential schools. Ottawa: AFN. 
Baker, J., Lynch, K., Cantillon, S., \& Walsh, J. (2004). Equality: From theory to action. Basingstoke: Palgrave Macmillan.

Battiste, M., \& Henderson, J. (2009). Animating Indigenous knowledge in education. Canadian Journal of Native Education, 32(1), 5-18.

Bischoping, K., \& Fingerhut, N. (1996). Border lines: Indigenous peoples in genocide studies. Canadian Review of Sociology, 33(4), 481-506.

Blackstock, C. (2008). Reconciliation means not saying sorry twice: Lessons from child welfare in Canada. In M. B. Castellano, L. Archibald, and M. DeGagné (Eds.), From truth to reconciliation: Transforming the legacy of residential schools (pp. 163-178). Ottawa: The AHF.

Brym, R., \& Nakhaie, M. (2009). Professional, critical, policy, and public academics in Canada. Canadian Journal of Sociology, 34(3), 655-669.

Brasfield, C. (2001). Residential school syndrome. BC Medical Studies, 34(2), 78-81.

Brown, L., \& Strega, S. (2005). Research as resistance. Toronto: Canadian Scholars' Press.

Burawoy, M. (2005). 2004 American sociological association presidential address: For public sociology. American Sociological Review, 70, 4-28.

Canadian Bar Association. (2005). The logical next step: Reconciliation payments for all Indian residential school survivors. Ottawa: Canadian Bar Association.

Castellano, M. B., Archibald, L., \& DeGagné, M. (2008). From truth to reconciliation: Transforming the legacy of residential schools. Ottawa: AHF.

Chrisjohn, R., \&Young, S. (1997). The circle game: Shadows and substance in the Indian residential school experience in Canada. Penticton , BC: Theytus Books.

DeGagné, M. (2001). Moving forward. Proceedings from the reparations for the stolen generations conference, August 15 - 16, University of New South Wales, Sydney, Australia.

Delgado, R. (2001). Critical race theory: An introduction. New York: New York University Press.

Diamond, A. (2011). Unrepentant: Disrobing the emperor. Book review. The Montreal Review, March 2011.

Dickson-Gilmore, E. J., \& La Prairie, C. (2005). Will the circle be unbroken? Aboriginal communities, restorative justice and the challenges of conflict and change. Toronto: University of Toronto Press.

Dyck, N. (1997). Tutelage, resistance and co-optation in Canadian Indian administration. Canadian Review of Sociology, 34(3), 333-348.

Episkenew, J. -A. (2009). Taking back our spirits. Winnipeg, Manitoba: University of Manitoba Press.

First Nation Child and Family Caring Society [FNCFCS]. (2012). Annual report 2011/12. Ottawa: FNCFCS.

Gartrell, B. (1986). 'Colonialism' and the fourth world: Notes on variations in colonial situations," Culture 6(1), 3-17.

Grant, A. (1996). No end of grief: Indian residential schools in Canada. Winnipeg: Pemmican Publications.

Haig-Brown, C. (1988). Resistance and renewal: Surviving the Indian residential school. Vancouver: Arsenal Pulp Press Ltd.

Hodzic, R. (2011). Canada needs reckoning with continued impact of residential schools. International Center for Transitional Justice, July 13. Retrieved November 2, 2012 from http://ictj.org/news/canada-needs-reckoning-continued-impact-residential-schools

Indian Residential Schools Truth and Reconciliation Commission [IRS TRC]. (2008). Our mandate. Retrieved May 11, 2012 from http://www.trc.ca/websites/trcinstitution/index.php?p=7.

Ivison, D., Patton, P., \& Sanders, W. (2000). Political theory and the rights of Indigenous peoples. Cambridge: Cambridge University Press.

Kiss, E. (2000). Moral ambition within and beyond political constraints: Reflections on restorative justice. In R. I. Rotberg and D. Thompson (Eds.), Truth v. justice: The morality of truth commissions (pp. 68-99). Princeton: Princeton University Press. 
Kovach, M. (2009). Indigenous methodologies. Toronto: University of Toronto Press.

Kulchyski, P. (2010). "Turning the page on colonial oppression: Defenders of the Land meets in Vancouver." Canadian Dimension, 44(2), March-April 2010, 12 paragraphs. Retrieved March 28, 2012 from http://canadiandimension.com/articles/2815/

LaPrairie, C. (1998). The 'New' justice: Some implications for Aboriginal communities. Canadian Journal of Criminology, 40(1), 61-79.

LaPrairie, C. (1999). The impact of Aboriginal justice research on policy: A marginal past and an even more uncertain future. Canadian Journal of Criminology 41(2), 249-260.

MacKenzie, I. (2009). For everything there is a season. In G. Younging, J. Dewar, and M. DeGagné (Eds.), Response, responsibility, and renewal: Canada's truth and reconciliation journey (pp. 8796). Ottawa: The AHF.

Miller, J. (1996). Shingwauk's vision: A history of Native residential schools. Toronto: University of Toronto Press.

Miller, J. (2000). Skyscrapers hide the heavens: The history of Indian-White relations in Canada. Toronto: University of Toronto Press.

Milloy, J. S. (1999). A National crime: The Canadian Government and the residential school system 1879 to 1986. Winnipeg, Manitoba: The University of Manitoba Press.

Minow, M. (1998). Between vengeance and forgiveness. Boston: Beacon Press.

Monchalin, L. (2009). Aboriginal peoples' safety: Strategic overview. Ottawa: Institute for the Prevention of Crime.

Monture-Angus, P. (1999). Journeying forward. Halifax: Fernwood Publishing.

Mussell, (2008). Decolonizing ducation: A building block for reconciliation. In M. B. Castellano, L. Archibald, and M. DeGagné (Eds.), From truth to reconciliation: transforming the legacy of residential schools (pp. 321-340). Ottawa: The AHF.

Native Women's Association of Canada [NWAC]. (2011). From residential schools to prisons, April 2011. Retrieved November 2, 2012 from http://www.nwac.ca/sites/default/files/imce/WEBSITES/201104/insert1 final\%20web\%20english.pdf

Nielsen, M. (1994). Criminal justice and native self-government. In R. Silverman and M. Nielsen (Eds.), Aboriginal peoples and Canadian criminal justice (pp. 243-259). Toronto: Harcourt.

Nielsen, M., \& Robyn, L. (2003). Colonialism and criminal justice for Indigenous peoples in Australia, Canada, New Zealand and the United States of America. Global Indigenous Nations Studies Program, University of Kansas.

Nielsen, M., \& Zion, J. (2005). Navajo nation peacemaking. Tucson: University of Arizona Press.

Nielsen, M., \&Gould, L. (2007). Non-Native scholars doing research in Native communities: A matter of respect. The Social Sciences Journal, 44(3), 420-433.

O'Connor, P. (2000). Squaring the circle: How Canada is dealing with the legacy of Indian residential school experiment. Australian Journal of Human Rights, 6(1), 188-217.

O'Connor, P. (2006). Private troubles, public issues: The Irish sociological imagination. Irish Journal of Sociology, 15(2), 5-22.

Olsen, G. (2002). The politics of the welfare state: Canada, Sweden and the United States. Don Mills: Oxford University Press.

Royal Commission on Aboriginal Peoples. (1996). The report of the royal commission on Aboriginal peoples. Ottawa: Library of Parliament.

Schissel, B., \& Wotherspoon, T. (2003). The legacy of school for Aboriginal people. Oxford: Oxford University Press.

Sider, D. (2005). A sociological analysis of root causes of Aboriginal homelessness in Sioux Lookout, Ontario. Toronto, ON: The Canadian Race Relations Foundation.

Smith, A. (2007). Soul wound: The legacy of Native American schools. Amnesty International Magazine. March 26, 2007, 30 paragraphs. Retrieved March 28, 2013 from http://www.amnestyusa.org/node/87342 
Smith, A. (2009). Indigenous peoples and boarding schools: A comparative study. Paper Secretariat of the United Nations Permanent Forum on Indigenous Issues. New York, 18 - 29.

Smith, L. T. (1999). Decolonizing methodologies: Research and Indigenous peoples. Dunedin: University of Otago Press.

Stenning, P., \& Roberts, J. (2001). "Empty Promises: Parliament, the Supreme Court, and the Sentencing of Aboriginal Offenders." Saskatchewan Law Review, 64, 137-168.

Stout, M., \& Kipling, G. (2003). Aboriginal people, resilience and the residential school legacy. Ottawa: Aboriginal Healing Foundation.

Strang, H., \& Braithwaite, J. (2001). Restorative justice and civil society. Cambridge: Cambridge University Press.

Turner, J. (2005). Is public sociology such a good idea? American Sociologists, 36(3-4), 27-45.

Waldram, J. B. (2009). Culture and aboriginality in the study of mental health. In L. J. Kirmayer and G. G. Valaskakis (Eds.). Healing traditions: The mental health of Aboriginal peoples in Canada (pp. 56-79). British Columbia: UBC Press.

Wilson, S. (2008). Research is ceremony: Indigenous research methods. Halifax: Fernwood Publishing. United Nations. (2009). Promotion and protection of all human rights, civil, political, economic, social, and cultural rights, including the right to development. Report release by General Assembly on February 17, 2009.

Younging, G., Dewar, J., \& DeGagné, M. (2009). Response, responsibility, and renewal: Canada's truth and reconciliation journey. Ottawa: The AHF. 